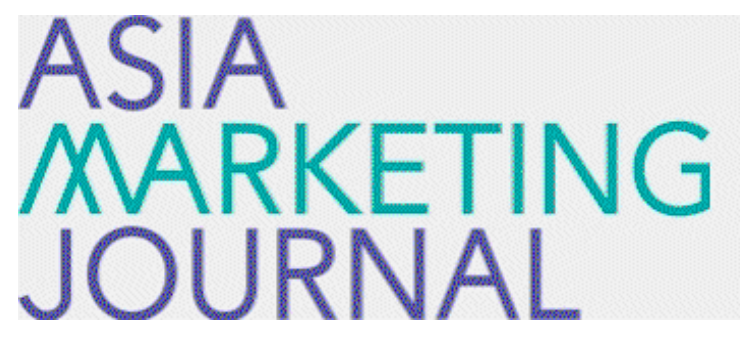

ASIA MARKETING JOURNAL

Volume 17 | Issue 3

Article 6

10-31-2015

\title{
ASIA MARKETING JOURNAL 제17권 제3호 목차
}

Follow this and additional works at: https://amj.kma.re.kr/journal

Part of the Marketing Commons

\section{Recommended Citation}

(2015) "ASIA MARKETING JOURNAL 제17권 제3호 목차," Asia Marketing Journal: Vol. 17 : Iss. 3 , Article 6.

Available at: https://doi.org/10.53728/2765-6500.1408

This Article is brought to you for free and open access by Asia Marketing Journal. It has been accepted for inclusion in Asia Marketing Journal by an authorized editor of Asia Marketing Journal. 


\section{Vol. 17 No. 03 October 2015}

\section{$<$ Research Paper>}

The Roles of Money's Pride and Surprise Tag on the Use of Money

Cong Liu - Nak Hwan Choi

The Antecedents and Consequences of Effective Brand Positioning

Changju Kim - Eunji Seo - Junghwa Hong · Sangmin Kang - Stephen J. Newell

Exploratory Study of the Impact of Social Media Marketing on Consumer

Purchase Intention: Comparative Study of Pakistan and South Korea

Tayyaba Noreen · Sang-Lin Han

The Effect of New brand's Entry on the Price Strategy of Incumbent Retailers

Suhhyue Lee

Comparison of Experienced and Inexperienced Consumers' Utilisation

of Extrinsic Cues in Product Evaluation: Evidence from the Korean Fine Arts Market

Yoonjeun Kim - Kiwan Park - Yaeri Kim • Youngmok Chung 